\section{Developing the scholarship of medical educators: a challenge in the present era of change}

\section{John Sandars, Martin J McAreavey}

Medical education is in an era of rapid change. The main driver appears to be a desire to improve the quality of medical education, but how can this be achieved?

$\mathrm{T}$ he aim of scholarship of teaching and learning can be simply stated as making transparent the process by which the educator has made learning possible. ${ }^{1}$ Schulman has extended this definition to include the essential aspects of professionalism, pragmatism and policy. ${ }^{2}$ Professionalism is the most important reason for engaging in the scholarship of teaching and learning. In this aspect of scholarship, expertise is recognised and respected by individuals and organisations that are both internal and external to the profession of medical education. Pragmatism reflects the art and craft of the medical educator. This aspect includes instructional knowledge, such as knowing how to develop teaching materials, construct assessments or lead groups. Policy is an inherent part of medical education and all medical educators are enmeshed in webs of national and local policy that direct how education should be delivered.

The Academy for Medical Educators is currently recruiting foundation members (http://www.asme.org.uk/academy/academy faq.htm). It has an overall aim to develop and sustain medical education as an academic discipline. This is an important milestone in the journey of ensuring that medical education becomes a recognised professional discipline in the UK. Our experience suggests that few educators apply the same degree of scholarship to medical education as they do to their other professional discipline, such as being a physician or being a general medical practitioner. The potential of the new academy to improve the quality of medical education will be determined by its membership and their understanding of the nature of the scholarship of medical education.

Several criteria can be used to evaluate the excellence of medical educators, ${ }^{3}$ and the Group of Educational Affairs of the Association of American Colleges has produced a range of criteria to evaluate scholarship. ${ }^{4}$ These criteria can provide a useful checklist for admission to the academy, but improved quality in medical education will only occur if there is evidence that can clearly demonstrate the impact of the individual educator on teaching and learning. ${ }^{5}$

Improved quality of medical education requires sustained local action, with strong leadership, adequate resources, academic recognition and regular peergroup meetings. ${ }^{6}$ Appointment and promotion boards often appear to give little academic recognition for the scholarship of education and this must be overcome. It is also essential for groups of medical educators to regularly meet to question their approach to teaching and learning. ${ }^{7}$ An important aspect of the scholarship of medical education is the critical evaluation of day to day teaching activity and this can have an inquiry led focus, with the development of research into practice. ${ }^{8}$ We suggest that very few medical educators regularly participate in this aspect of scholarship.

The new Academy for Medical Educators is an essential step in the future scholarship of medical educators, but improved quality in medical education in this present era of change will require all medical educators to have a commitment to engage in peer led inquiry into their day to day educational practice. This personal responsibility to scholarship is a challenge to all medical educators and the academy will need to respond by providing strong leadership, professional recognition and support at both local and national levels.

Postgrad Med J 2007;83:561.

doi: 10.1136/pgmi.2007.059352

\section{Authors' affiliations}

John Sandars, Medical Education Unit, The University of Leeds, Leeds, UK

Martin J McAreavey, School of Medicine, The University of Leeds, UK

Correspondence to: Dr John Sandars, Medical Education Unit, The University of Leeds, 20 Hyde Terrace, Leeds LS2 9LN, UK; i.e.sandars@leeds. ac.uk

Competing interests: None.

\section{REFERENCES}

1 Martin E, Ramsden P. Introduction. Special issue: scholarship of teaching, Higher Education Research and Development 2000;24:163-77.

2 Shulman LE. From Minsk to Pinsk: why a scholarship of teaching and learning. Journal of Scholarship of Teaching and Learning 2000;1:48-52.

3 Hesketh EA, Bagnall G, Buckley EG, et al. A framework for developing excellence as a clinical educator. Med Educ 2001;35:555-64.

4 Fincher R-ME, Simpson DE, Mennin SP, et al. Scholarship in teaching: an imperative for the $21 \mathrm{st}$ century. Acad Med 2000;75:887-894.

5 Glick TH. How best to evaluate clinician-educators and teachers for promotion? Acad Med 2002;77:392-7.

6 Gruppen LD, Frohna AZ, Anderson RM, et al. Faculty development for educational leadership and scholarship. Acad Med 2003;78:137-41.

7 Edwards K. "Short stops": peer support of scholarly activity. Acad Med 2002;77:939.

8 Elliott J. Action research for educational change. Milton Keynes: Open University Press, 1991. 